\title{
Climate Finance: Unlocking Funds Toward Achievement of Climate Targets Under the Paris Agreement
}

\author{
Ackom, Emmanuel; Motty, M.
}

Published in:

Climate Action. Encyclopedia of the UN Sustainable Development Goals

Link to article, DOI:

10.1007/978-3-319-71063-1_104-2

Publication date:

2019

Document Version

Peer reviewed version

Link back to DTU Orbit

Citation (APA):

Ackom, E., \& Motty, M. (2019). Climate Finance: Unlocking Funds Toward Achievement of Climate Targets Under the Paris Agreement. In Climate Action. Encyclopedia of the UN Sustainable Development Goals https://doi.org/10.1007/978-3-319-71063-1_104-2

\section{General rights}

Copyright and moral rights for the publications made accessible in the public portal are retained by the authors and/or other copyright owners and it is a condition of accessing publications that users recognise and abide by the legal requirements associated with these rights.

- Users may download and print one copy of any publication from the public portal for the purpose of private study or research.

- You may not further distribute the material or use it for any profit-making activity or commercial gain

- You may freely distribute the URL identifying the publication in the public portal 


\section{Climate Finance: Unlocking Funds Toward Achievement of Climate Targets Under the Paris Agreement}

Motty M., Ackom E.K. (2019). Climate Finance: Unlocking Funds Toward Achievement of Climate Targets Under the Paris Agreement. In: Leal Filho W., Azul A., Brandli L., Özuyar P., Wall T. (eds) Climate Action. Encyclopedia of the UN Sustainable Development Goals. Springer, Cham

DOI: https://doi.org/10.1007/978-3-319-71063-1_104-2

\section{Introduction: Understanding the Current Climate Financial Landscape}

There is an undeniable urgency on the need to finance climate change activities with high greenhouse gas (GHG) emission reduction impact. The 2018 Intergovernmental Panel on Climate Change (IPCC) special report on the impacts of global warming of $1.5^{\circ} \mathrm{C}$ above preindustrial levels and related global GHG emission pathways confirms that warming greater than the global annual average is already being experienced in many regions (IPCC 2018). Additionally, the 2018 Emission Gap Report by the UN Environment reiterates the unlikeliness of holding global warming below $2{ }^{\circ} \mathrm{C}$ if current GHG emission trends prevail. The emission reduction efforts described in current national actions plans submitted by countries under the Paris Agreement on Climate Change would need to be tripled by 2030 to avoid a $2{ }^{\circ} \mathrm{C}$ warming scenario and increased fivefold for the $1.5^{\circ} \mathrm{C}$ warming threshold (UNEP $\underline{2018})$.

Without a doubt, reducing GHG emissions will require massive new and additional investments. The importance of aligning financial flows to provide developing countries with low-emission technologies and climate-resilient development pathways is now more critical than ever to deliver on the 2030 Agenda for Sustainable Development and meet the Paris Agreement on Climate Change. But out of all the challenging conversations at the core of negotiations under the United Nations Framework Convention on Climate Change (UNFCCC), dealing with money is arguably one of the most persistent and difficult.

Based on the common but differentiated responsibilities and fair principles, the Convention requires developed countries to assume historical responsibility by providing new and additional financial resources to Parties from developing states in support of climate action implementation (Zhang and Pan 2016). However, developed and developing countries known under the convention as Annex 1 and non-Annex 1 countries interpreted this entry differently. Over the years, this misunderstanding between parties created a rift in expectations, delivery, accountability, use, and access of funds. Consequently, this misinterpretation created gaps in the execution and disbursement of funds where it is most needed.

For example, it has been argued that one of the more controversial estimates on climate finance flows is the US\$ 100 billion figure that was introduced as part of the Copenhagen Accord in 2009. For a background, at the 15th Conference of Parties (COP15), Annex 1 countries committed to providing 30\$US billions of fast-track finance between 2010 and 2012, promising to mobilize US\$ 100 billion per year of long-term climate finance starting in 2020 (Weikman and Roberts 2019). Following the Copenhagen Accord in 2009 was the Cancun 
Agreement in 2010, which defined the US\$ 100 billion to include public contribution as well as mobilized private sector funds. It was, however, never decided how different public sector instruments will be accounted for nor which criteria will be applied to define the private sector contribution. Furthermore, this figure does not refer to needed global investment but rather represents only the funding to be provided to developing countries by developed countries. It has also been argued that the US\$ 100 billion amount was derived without much justification and evidence for the chosen amount from concrete assumptions on financing requirements for climate action (Sterk et al. 2011). Additionally, many developing countries on the one hand have highlighted the need for scaled-up international support (including finance) in implementing the Paris Agreement and the difficulties countries face to access the existing funds under the various financial mechanisms (Hedger and Nakhooda 2015). On the other hand, the real absorptive capacity by some developing countries to handle relatively large volume of climate funds, in the absence of robust fiduciary framework, has been raised by some developed countries. Additionally, there is growing expectation from developed countries for emerging economies such as China and India to contribute to global climate finance in the future based on their capacities.

Ensuring that sufficient finance and investment is available, accessible, trackable, and used for purpose will be the major challenge going forward. It is essential to bridge the gaps and barriers to unlock funds, in order to maintain temperature below $1.5 \mathrm{C}$ under the Paris Agreement rulebook, hence the rationale for this entry.

\section{Gaps in Identifying Climate Finance Contributions}

There is an ongoing debate about the types of funding to be considered as climate finance. A report released by the Organization for Economic Co-operation and Development and Climate Policy Initiative (OECD-CPI), ahead of the Paris Agreement negotiations in 2015, indicated how much funds developed countries are delivering to developing countries as part of the US\$ 100 billion pledge (OECD 2015).

The OECD-CPI report put forward the following figures, that is, US\$ 52 and 62 billion in years 2013 and 2014, respectively, and argued its relevance for the US\$ 100 billion goal. While the report attempted to illustrate how developed countries are achieving their collective pledge, it did not have the desired effect for developing countries. Non-Annex 1 countries questioned the report's methodology in calculating the contributions. For example, speaking on behalf of the G77 + China, a chief negotiator at the United Nations climate talks in Bonn was quoted as saying: "I am not able to comment on or judge the report because we don't know the veracity, credibility and the methodology of the report or who was consulted. Developing countries were not. It has no status in the UN negotiations. It was not commissioned under the mandate of the UNFCCC" (Quoted in Sethi 2015; Weikman and Roberts 2019).

Another developing country negotiator was quoted as saying "The OECD calculations include non-concessional loans and existing overseas development assistance provided to developing countries. How can these be regarded as climate finance flows when the climate convention clearly states the flows are to be new and additional?" (Quoted in Sethi 2015; Weikman and Roberts 2019).

Non-Annex 1 countries seem to have questioned the legitimacy of the report stating that since the report was not commissioned under the mandate of the UNFCCC, it held no legality under 
the convention. They also rejected the report's conclusions (Indian Ministry of Finance 2015). After the release of the report, a senior advisor in a Ministry of Finance from a developing country who is also a climate finance negotiator was quoted as saying: "The most fundamental assessment should have been that the total flows (of climate finance) provided by the developed countries should be matched to the total flows received by the developing countries. The report is silent on this" (Quoted in Sethi 2015; Weikman and Roberts 2019).

Since national plans vary greatly in content from one country to another and a number of countries focus on both adaptation and mitigation actions, it is important to determine the types of funding to be considered as climate finance. However, the Paris agreement does not seem to provide enough clarity in this area.

\section{Gaps in Tracking Climate Finance Flows}

There is no commonly agreed format to report on the financial support received, nor is there a common methodology for evaluating the financial support received. Determining how to account resources mobilized through the private sector is still a lingering challenge (Caruso and Ellis 2013). In addition, the UNFCCC guidelines do not require information on the underlying assumptions, definitions, and methodologies used to generate the information on climate finance received or methodologies for performance evaluations in the mobilization of private climate finance.

The Standing Committee on Finance (SCF) which assists the COP in measuring, reporting, and verification of financial mechanisms support provided to developing country Parties delivered a progress report on the matter at the COP24 (UNFCCC 2018). The 2018 Biennial Assessment (BA) and Overview of Climate Finance Flows included, for the first time, information relevant to Article 2, paragraph 1(c), of the Paris Agreement, including methods and metrics and data sets on flows, stocks, and considerations for integration (UNFCCC $\underline{2018)}$.

While continued efforts to make climate finance information more accessible and transparent have been made, not only by governments from recipient countries and donors but also by nongovernmental (international, regional, and local) organizations, issues around the transparency of financial contributions persist. Under the Paris Agreement, provisions regulating climate finance contributions and its reporting obligations are not legally binding (Ferreira 2018). As demand for international climate finance flows is set to rise, transparency is an important tool for building trust between developed and developing country partners. Methodological issues relating to measurement, reporting, and verification of public and private climate finance flows persist, making identifying and quantifying the financial contributions challenging. Improving the effectiveness of climate finance accounting, reporting, and overall transparency is imperative.

\section{Gap in Raising Public Funds for Climate Finance}

Another gap is the apparent inability by developed countries to raise the promised amount via public finance mechanism. The amount of investment needed to address climate change is projected to surpass the US\$ 100 billion per year target. To prevent the worst impacts of climate change, net additional investment of around US\$ 4 trillion (about US\$ 270 billion per year) will be needed (Global Commission on the Economy and Climate 2014). This cost 
represents only a $5 \%$ increase over the business-as-usual scenario and is likely to be offset in the longer term by fuel cost savings (Global Commission on the Economy and Climate 2014).

Article 9 of the Paris Agreement stipulates that Annex 1 Parties shall provide financial resources to assist developing country Parties as well as lead in mobilizing climate finance from a wide variety of sources, instruments, and channels, noting the significant role of public funds, through a variety of actions, including supporting country-driven strategies, and taking into account the needs and priorities of developing country Parties (UNFCCC 2015).

In general, public climate finance supports projects and aims to address market failures. In that regard, public funds have the ability to close funding gaps which would exist if only the private sector could provide financing (Clark et al. 2018). On one hand, developed countries have contributed through grants. However, studies have shown that reaching the US\$ 100 billion goals is unlikely unless a major part of the funds stemming from public funds are disbursed as concessional loans (Westphal et al. 2015).

Part of these public funds finance multilateral climate finance mechanisms. More precisely, the Convention established a financial mechanism with operating entities that are accountable to the COP. The Global Environment Facility (GEF) was established in 1994 and the Green Climate Fund (GCF) in 2011 as an operating entity of the financial mechanism. The GEF also manages the Special Climate Change Fund (SCCF) and the Least Developed Countries Fund (LDCF). In addition to these funds, the Adaptation Fund (AF) was established under the Kyoto Protocol in 2001.

These funds are replenished through contributions from developed countries. The latest assessment report from the SCF indicates that multilateral climate fund total amounts channelled through UNFCCC funds and multilateral climate funds in 2016 were US\$ 2.4 billion (UNFCCC 2018). That same year, climate finance from multilateral development banks provided US\$ 25.5 billion in climate finance from their own resources to eligible recipient countries (UNFCCC $\underline{2018}$ ) (Fig. 1).

\section{Fig. 1}

Characteristics of international public climate finance flows in the period 2015-2016. (Source: UNFCCC $\underline{2018}$ )

\begin{tabular}{|c|c|c|c|c|c|c|c|c|}
\hline & \multirow{2}{*}{$\begin{array}{l}\text { Annual } \\
\text { average } \\
\text { USD billion }\end{array}$} & \multicolumn{4}{|c|}{ Area of support } & \multicolumn{3}{|c|}{ Financial instrument } \\
\hline & & Adaptation & Mitigation & REDD-plus $^{\circ}$ & Cross-cutting & Grants & $\begin{array}{c}\text { Concessional } \\
\text { loans }\end{array}$ & Other \\
\hline $\begin{array}{l}\text { Multilateral } \\
\text { climate funds }^{b}\end{array}$ & 1.9 & $25 \%$ & $53 \%$ & $5 \%$ & $17 \%$ & $51 \%$ & $44 \%$ & $5 \%$ \\
\hline $\begin{array}{l}\text { Bilateral } \\
\text { climate finance }^{c}\end{array}$ & 31.7 & $29 \%$ & $50 \%$ & - & $21 \%$ & $47 \%$ & $52 \%$ & $<1 \%$ \\
\hline $\begin{array}{l}\text { MDB climate } \\
\text { finance }^{d}\end{array}$ & 24.4 & $21 \%$ & $79 \%$ & - & - & $9 \%$ & $74 \%$ & $17 \%$ \\
\hline
\end{tabular}

The summary and recommendations of the 2018 Biennial Assessment and Overview of Climate Finance flows of the Standing Committee on Finance presented at the COP24 highlighted that financial flows increased by 17\% in 2015-2016 from 2013-2014 levels. It was indicated that part of this increase was due to high levels of new private investment in 
renewable energy (UNFCCC 2018). The total finance reported in 2016 was of US\$ 38 billion, out of which US\$ 34 billion was reported as climate-specific finance and channelled through bilateral, regional, and other channels; the remainder flowed through multilateral channels (UNFCCC 2018).

Furthermore, the World Economic Forum (WEF) Green Investment Report stipulates that additional, incremental investment in the order of US\$ 700 billion per year would be needed to meet the global climate change challenge with regard to clean energy infrastructure, lowcarbon transport, energy efficiency, and forestry (Green Growth Action Alliance 2013).

The WEF estimate reiterates that new kinds of investments are needed to achieve sustainability goals. Although the annual US\$ 100 billion target is set for 2020 on, the 2016 figures clearly indicate the gap in raising the promised amount by developed country through public finance mechanisms.

\section{Challenges in Tracking New and Additional Climate Finance}

New and additional funds refer to resources being mobilized that are beyond existing development cooperation budgets, but funders have yet to define what constitute additional funds (Stadelmann et al. 2011). In the absence of an internationally agreed definition of the terms "new and additional" climate finance in the UNFCCC, each country has its own definition of these terms. As a result, each member state can decide what is considered climate finance and why is that climate financing option "new and additional." For example, some developed countries account all financial instruments toward climate action at nominal cash value (OECD 2015). This means that developed countries could possibly opt to count loans they grant to developing countries as climate finance.

This loose definition creates overlaps between development assistance and climate financing. The table below was prepared by the United Nations Conference on Trade and Development (UNCTAD) and illustrates a number of interpretations of what additional official flows for climate change mean for different developed countries (UNCTAD $\underline{2015}$ ).

Under the first option showcased, climate finance is considered additional if it is over and above the $0.7 \%$ official development assistance (ODA) or gross national income target. This percentage was established in 1970 by the Development Assistance Committee (DAC) of OECD to measure aid. It was prepared before climate change was recognized and therefore did not factor in the additional finance needed to tackle climate change. The second optional definition for climate finance sets a reference year as the baseline for expenditures relevant to climate finance. The reference year is determined at the discretion of the country, and the additional climate investments can be set on a random amount or percentage, i.e., 2018 climate finance contribution for country A would be of one million USD above 2009 investments or as another example, country B would, for 2018, dedicate funds $3 \%$ above 2017 climate finance flows. The third option suggests that finance for climate change should be included in the country's development aid funding but limited to 10\% of ODA. Depending on the country's pledges to the various financial mechanism and bilateral development aid, additional funding might be needed. Under the fourth option, new source considered additional stem from other alternative sources of finance such as international air transport levies, currency trading levies, or auctioning of emission allowances (Knoke and Duwe 2012) (Table 1).

Table 1 
Summary of climate finance definitions

\begin{tabular}{|c|c|c|}
\hline$\overline{\text { Options }}$ & Definitions & $\begin{array}{c}\text { Member States currently in support of } \\
\text { options }\end{array}$ \\
\hline $\begin{array}{l}\text { Option } \\
1\end{array}$ & $\begin{array}{l}\text { Funding above the } 0.7 \% \\
\text { ODA target }\end{array}$ & $\begin{array}{l}\text { Denmark, developing countries, } \\
\text { Luxembourg, the Netherlands, Norway, } \\
\text { Sweden }\end{array}$ \\
\hline $\begin{array}{l}\text { Option } \\
2\end{array}$ & $\begin{array}{l}\text { Increase in current levels of } \\
\text { climate finance (reference } \\
\text { year, 2009) }\end{array}$ & $\begin{array}{l}\text { Austria, Estonia, Finland, Germany, } \\
\text { Slovenia, Spain }\end{array}$ \\
\hline $\begin{array}{l}\text { Option } \\
3\end{array}$ & $\begin{array}{l}\text { Funding additional to the } \\
\text { level of ODA spending in } \\
\text { nominal terms }\end{array}$ & $\begin{array}{l}\text { Belgium, European Commission, } \\
\text { Hungary, Latvia, Portugal, Slovak } \\
\text { Republic, United Kingdom }\end{array}$ \\
\hline $\begin{array}{l}\text { Option } \\
4\end{array}$ & $\begin{array}{l}\text { Increase in climate finance } \\
\text { from new sources }\end{array}$ & Germany, Poland \\
\hline
\end{tabular}

Source: UNCTAD (2015)

It is understood from the table above that budgets of multi-sectorial development programs with a climate action component are reported and counted as climate finance. This reporting method results in double accounting of financing for development environmental aid and climate finance.

While criteria for ODA have been defined quite clearly, there is no such clear-cut definition for climate finance. At the same time, there are considerable overlaps, both geographical and sectoral, between development and climate change issues that add a level of complexity when tracking climate-specific funding. 


\section{Challenges for Developing Countries to Access Funding}

\section{Stringent Rule}

Provisions were added under the Paris Agreement to allow non-Annex 1 countries most vulnerable to climate change to access funds. Notably, it is understood that relevant operating financial entities of the convention are required to ensure efficient access to financial resources through simplified approval procedures and enhanced readiness support for Least Developed Countries and Small Island Developing States, in the context of their national climate strategies and plans (UNFCCC 2018). However, the various rules and regulations to the funds complicate direct access to the funds, especially by some of the most vulnerable countries. Taking the example of the Green Climate Fund (GCF), the extensive rules surpass capacities of a number of countries. For instance, if a country would want any of its national departments to become an official entity and direct recipient of GCF funds, then that institution needs to undergo the GCF's accreditation. This rigorous process would lead the nominated national entity to demonstrate the compliance with the funds fiduciary and gender policy standards and environmental and social safeguards as well as have a track record of delivering mitigation and adaptation projects and show functional independent audit committee over the past 3 years, various procurement committees, relevant guidelines and data on complaints handled in the past 2 years, examples of conflicts of interest in the past 2 years and how they were dealt with, and so on (Green Climate Fund 2017). The GCF also has a special readiness program to support developing countries' institutions through the accreditation process.

While due diligence is a vital exercise, the current process meant to accelerate access might not in actuality enable the desired result for reasons beyond the fund's mechanism. As an example, Africa holds 33 out of 47 Least Developed Countries, and these countries are also in need of the readiness program. Unfortunately, these countries happen to be ranked high in Transparency International's perceived corruption report, adding a level of difficulty in compliance to some transparency requirements of the GCF to obtain accreditation (Fig. 2). 


\section{LOWEST SCORING REGION}

\section{SUB-SAHARAN AFRICA}
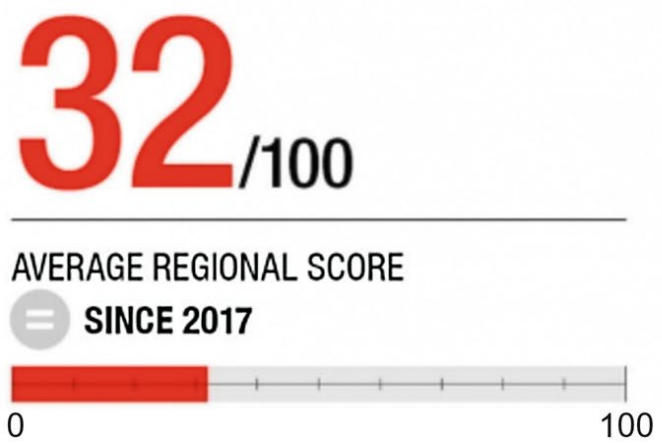

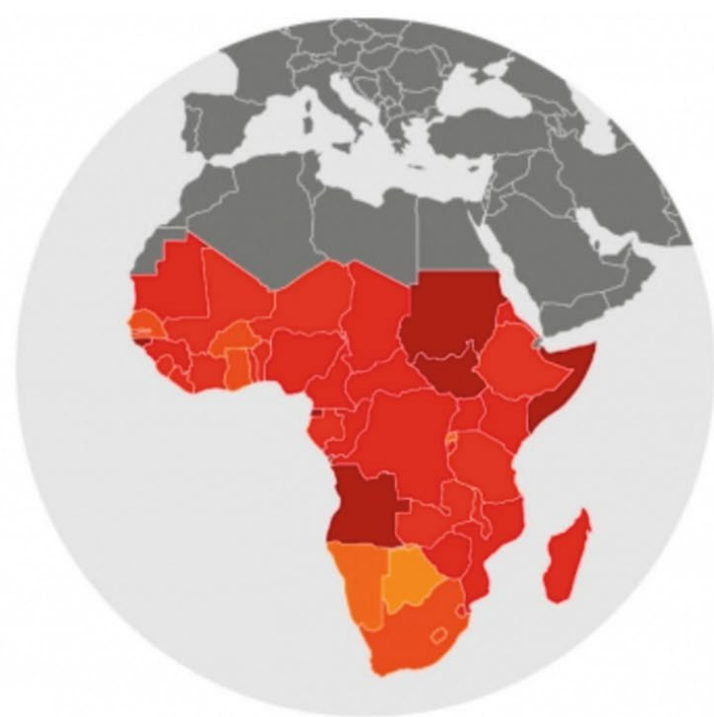

Alternatively, some countries opt to access the funds through multilateral institutions that are already GCF accredited or that have the means to become accredited quickly. As designated entities, the multilateral institutions also have greater input in allocation of funds to the country to support national processes in the GCF Readiness activities. This substitute approach then puts into question the level of immediate ownership, control, and accountability of GCF projects by countries taking this route until after a period of time when capacity in the recipient country has been built by the multilateral institution providing GCF support. The question therefore is how to, in a concerted manner, improve the system to facilitate an expedited capacity building initiatives in developing countries to enable them access directly the GCF.

\section{Lack of National Coordination and Fragmentation of Climate}

\section{Financing Sources}

The fragmentation of financing sources and funding priorities presents accessibility challenges. Recent reports on development aid in general have indicated that increased coordination of development and climate-related activities among various donors operating in a country increases the transparency of resource commitments and delivery (Lundsgaarde et al. 2018). Other reports have highlighted the fact that a number of developing countries show deficiency in their ability to successfully coordinate, at national level, donor programs and funding. This lack of organization ultimately makes it more challenging to identify financial needs at national level and to attract further financing (Halonen et al. 2017).

With regard to climate finance flows, a recent study by the World Resource Institute (WRI) concluded that the multiplicity of bilateral and multilateral climate funds creates in the end 
and overlaps in work programs as well as inconsistencies in procedures for accessing and managing funding (Amerasinghe et al. 2017).

Opportunities to improve practices did arise from these findings. For example, it has been concluded that a development aid project's success rate is greater when donors pay due diligence to recipient country's national priorities and the use of country systems for implementation of the activities (Abdel-Malek 2015). As climate finance funding opportunities increases, the need to ensure effective national coordination with regard to disbursement of funds, objectives of climate-related programs, and expenditures is paramount going forward.

\section{The Scale of Needed Investment}

Currently a reported US\$ 360 billion is invested annually in public and private climate investments, comprising of about US\$ 10-20 billion per year from developed countries governments, according to their fast-start finance reports and OECD estimates (OECD 2015). However, the amount that would be needed according to The Green Growth Action Alliance is US\$ 5.7 trillion (WEF 2018). This will however need to be invested annually in green infrastructure, especially in developing countries (Green Growth Action Alliance 2013). This will require shifting the world's US\$ 5 trillion in business-as-usual investments into green investments.

An estimate by the World Economic Forum indicates that the world will have to invest an estimated US\$90 trillion just in infrastructure over the next one and half decade. This translates to an increased in today's US\$3.4 trillion a year spending to US\$6 trillion. This kind of money will be needed to be able to invest in the needed ideas, businesses, and technologies that would yield GHG emission reductions (WEF 2018).

\section{Options to Alleviate the Barriers and Challenges to Unlocking Funds}

\section{Rethinking Public Source of Financing}

Historically, climate finance commitments under the climate change convention have been agreed through a top-down approach where developed countries committed a certain amount to the developing countries. Indeed, it has been agreed that developed countries have emitted over $75 \%$ of cumulative global GHG emissions since the mid-nineteenth century. Scientists have been able to illustrate that the occurring anthropogenic climate change is largely the result of these past emissions (IPCC 2018). Consequently, under the climate change convention, developed countries are responsible for transferring technologies and providing financial contributions for climate mitigation and adaptation investment in developing countries. However, as discussed above, a number of challenges and barriers in the current climate public financial mechanism prevent effective fund transfer to the developing countries.

One possible option would be to strengthen individual countries' capacity to absorb and manage climate funding through national initiatives. This approach could allow countries to get direct access to multilateral funds and consequently gain more ownership of climate 
actions being taken within their borders. For example, governments could set up a national financial entity dedicated to coordinate national climate strategies and be used as the official channel through which financing from international sources would transit by. The Brazilian Development Bank (BNDES), Corporación Financiera de Desarrollo (Cofide), Peru, South Africa's Development Bank of Southern Africa (DBSA), and Uganda Development Bank are all example of National Development Banks (NDB) that could, for example, be possibly considered for nationwide coordination of climate-related activities. The process for setting up such institutions is less stringent than acquiring accreditation as such local institutions, in addition to being largely government-led, are also dependent on domestic budgets and other macro- and microeconomic factors in-country (Inter-American Development Bank 2013). While national funding sources for climate adaptation and mitigation projects in developing countries are not as well established as the multilateral or bilateral financing agencies globally, the NDB could, for example, be used to provide a greater oversight of climate finance expenditures in a given country.

\section{Innovative Private Source of Financing}

Although efforts have been made to estimate private climate finance mobilized through multilateral and bilateral institutions, data on private finance sources and destinations are still lacking. The various private sector source of climate financing include debt investments and private equity investment management services, exchange, insurance companies, and pension funds and microfinance (Ruppel and Luedemann 2013). One way to better track private financing would be to create financial products specific to climate investments.

Microfinance, for example, is a form of financial services for small businesses and entrepreneurs but also households to access finance when they lack access to banking and related services. The main role for microfinance institutions (MFI) is to enhance financial inclusion at affordable costs to disadvantaged and low-income communities (Singh and Yadav 2012). A growing number of MFIs are also diversifying their products and services toward dedicated climate finance products. This shift can be seen in promoting clean energy products. Renewable energy solutions such as solar home systems and anaerobic digesters (biogas) are important to low-income families as they provide affordable access to clean energy and sometimes even new income-generating opportunities (Rippey 2009). MFI can help in accessing energy-efficient options for energy-intensive activities such as home cooking and lighting. MFI provide an opportunity for customers to leapfrog to energy-efficient intermediaries technologies at a reduced cost.

\section{Reducing Climate Finance Risk Through Financial Regulation}

Financial regulation supporting climate change action is currently uncommon but could be an option comparable to regulation targeting other secondary financial markets. Clear regulation is required to force the financial sector to drive global transformation toward a green economy. Standardized carbon accounting and reporting will contribute in elevating climate risks when considering financial investments. It is important that appropriate carbon metrics are used to ensure carbon performance is adequately assessed (Folger-Laronde and Weber 2018).

Traditionally, investors are only willing to invest on a short-term basis, while, on the other side, many climate-related projects (energy-efficient cooking and lighting, cooling systems, resilient infrastructure, etc.) projects require financial commitments for long-term investments. The Basel Committee on Banking Supervision (BCBS) is the primary global 
standard setter for the prudential regulation of banks (Basel Committee on Banking Supervision 2017). As such, the Basel's series, its International regulatory accord which seeks to improve the banking sector's ability to deal with financial stress, improve risk management, and strengthen the banks' transparency should be considerate of climate risks as well.

Recent revisions of the Basel III banking regulation resulted in higher capital requirements for banks when providing long-term loans (Basel Committee on Banking Supervision 2017). This updated requirement consequently discourages banks from long-term lending. Considering that climate finance investments are considered long-term, current international banking regulations do not entice investments in climate projects.

\section{Establishing a Monitoring, Verifying, and Reporting Framework for Climate Finance}

To achieve a more independent and sustainable development process, developing countries should be able to build up national capacities to monitor, report, and verify the various climate finance sources.

It is important for countries to identify the climate finance proportion included in the envelopes received for development assistance. Conducting a national mapping exercise of relevant multilateral and bilateral funds as well as private sector actors will provide clarity in terms of knowing the actual amount invested in climate actions. Establishing clear MRV modalities for accounting each financial assistance is key. Another key point to consider would be to create procedures and methodologies to isolate climate finance components in projects with multiple development objectives. For example, separate accounting of the nominal value of climate finance provided against the concessional components of the finance provided would be identified in the project's financial reporting.

\section{Conclusions}

A reported US\$ 5.7 trillion will need to be invested annually in green infrastructure, much of which will be in today's developing world (Green Growth Action Alliance 2013). This will require shifting the world's US\$ 5 trillion in business-as-usual investments into green investments. We are currently at US\$ 360 billion annually in public and private climate investments, with developed country governments providing somewhere between US\$10 and 20 billion per year, according to their fast-start finance reports and OECD estimates (OECD 2015). When one considers these figures, the US\$ 100 billion annual goal that is often referenced, though it is something to start with, is only a small piece of the US\$ 5.7 trillion puzzle. Both public and private levels of funding need sustained injection of funds and disbursements to ensure that the world get on a pathway to meeting investment needs in 2020 and beyond such as to help limit the global average temperature increase to $2{ }^{\circ} \mathrm{C}$ above preindustrial levels. Green investment can be scaled up to deliver sustained global growth through the implementation of the Paris Agreement. However, it is imperative to address the current urgent challenges and barriers that hinder access to needed climate finance funds.

\section{Definitions}

Climate finance: refers to local, national, or transnational financing - drawn from public, private, and alternative sources of financing - that seeks to support mitigation and adaptation actions that will address climate change (UNFCCC 2019). 
Concessional loan: loans that are extended on terms substantially more generous than market loans. The concessionality is achieved either through interest rates below those available on the market or by grace periods or a combination of these. Concessional loans typically have long grace periods (IMF 2003).

Nationally determined contributions (NDCs): The Paris Agreement establishes binding commitments by all Parties to prepare, communicate, and maintain a nationally determined contribution (NDC) and to pursue domestic measures to achieve them. It also prescribes that Parties shall communicate their NDCs every 5 years and provide information necessary for clarity and transparency (UNFCCC $\underline{2019}$ ).

Paris Agreement Article 2, paragraph 1(c): (c) Making finance flows consistent with a pathway toward low greenhouse gas emissions and climate-resilient development.

\section{Disclaimer}

The opinions and recommendations expressed in this entry are those of the authors and do not necessarily reflect the views of UNEP DTU Partnership, CTCN, and/or UNIDO. The designations employed and the presentation of the material in this publication do not imply the expression of any opinion whatsoever on the part of UNEP DTU Partnership, CTCN, and/or UNIDO concerning the legal status of any country, territory, city, or area or of its authorities. References to different sources have been made in this document.

\section{References}

1. Abdel-Malek T (2015) The global partnership for effective development cooperation: origins, actors, and future prospects. Bonn: DIE Studies 88 Google $\underline{\text { Scholar }}$

2. Amerasinghe N, Thwaites J, Larsen G, Ballesteros A (2017) The future of the funds: exploring the architecture of multilateral climate finance. World Resources Institute, WashingtonGoogle Scholar

3. Basel Committee on Banking Supervision (2017) High level summary of basel III reforms. Bank for International Settlements, BaselGoogle Scholar

4. Caruso R, Ellis J (2013) Comparing definitions and methods to estimate mobilised climate finance. OECD/IEA Climate Change Expert Group Papers, ParisGoogle Scholar

5. Clark R, Reed J, Sunderland T (2018) Bridging funding gaps for climate and sustainable development: pitfalls, progress and potential of private finance. Land Use Policy 71:335-346CrossRefGoogle Scholar

6. Ferreira PG (2018, Oct) Climate finance and transparency in the Paris agreement: key current and emerging legal issues. CIGI papersGoogle Scholar

7. Folger-Laronde Z, Weber O (2018) Climate change disclosure of the financial sector. Centre for International Governance Innovation, Waterloo Google $\underline{\text { Scholar }}$

8. Global Commission on the Economy and Climate (2014) Better growth, better climate. The new climate economy reportGoogle Scholar

9. Green Climate Fund (2017) Accreditation to the green climate fund. Green Climate Fund, SongdoGoogle Scholar 
10. Green Growth Action Alliance (2013) Green investment report: the ways and means to unlock private finance for green growth. World Economic Forum, GenevaGoogle Scholar

11. Halonen M, Illman J, Klimschaffskijj M, Sjoblom H, Rinne P, Roser F et al (2017) Mobilizing climate finance flows: nordic approaches and opportunities. Nordic Council of Ministers, DenmarkCrossRefGoogle Scholar

12. Hedger M, Nakhooda S (2015) Financing Intended Nationally Determined Contributions (INDCs): enabling implementation. Overseas Development Institute, LondonGoogle Scholar

13. IMF (2003) External debt statistics: guide for compilers and users - appendix III, glossary. IMF, Washington DCGoogle Scholar

14. Indian Ministry of Finance (2015) Climate finance, analysis of a recent OECD report: some credible facts needed. Retrieved 3 Mar 2019, from New Delhi: Department of Economic Affairs, Ministry of Finance, Government of India. http://pibphoto.nic.in/documents/rlink/2015/nov/p2015112901.pdf

15. Inter-American Development Bank (2013) The role of national development banks in catalyzing international climate finance. Inter-American Development Bank, WashingtonGoogle Scholar

16. IPCC (2018) Global warming of $1.5^{\circ} \mathrm{C}$, an IPCC special report on the impacts of global warming of $1.5^{\circ} \mathrm{C}$. Intergovernmental Panel on Climate Change, GenevaGoogle Scholar

17. Knoke I, Duwe M (2012) Climate change financing: the concept of additionality in the light of the commission proposal for a development cooperation instrument (DCI) for 2014-2020. European Parliament's Committee on Development, BrusselsGoogle Scholar

18. Lundsgaarde E, Dupuy K, Persson A (2018) Coordination challenges in climate finance. Copenhagen: Danish Institute for International Studies (DIIS) working paper 2018:3 Google Scholar

19. Nakhooda S, Watson C, Schalatek L (2016) The global climate finance architecture. Overseas Development Institute, LondonGoogle Scholar

20. OECD (2015) Climate finance in 2013-14 and the USD 100 billion goal. Organisation for Economic Co-operation and Development (OECD) in collaboration with Climate Policy Initiative (CPI), ParisGoogle Scholar

21. Quoted in Sethi (2015) Developing countries irked by report saying climate change funds delivered: OECD report says \$62bn given in 2014-15; developing nations allege creative accounting and greenwashing. Business Standard. http://www.business-standard.com/article/international/developing-countriesirked-by-report-sayingclimate-change-funds-delivered-115102200764 1.html

22. Rippey P (2009) Microfinance and climate change: threats and opportunities. CGAP, Washington, DCGoogle Scholar

23. Ruppel O, Luedemann C (2013) Climate finance: mobilizing private sector finance for mitigation and adaptation. Institute for Security StudiesGoogle Scholar

24. Singh J, Yadav P (2012) Micro finance as a tool for financial inclusion \& reduction of poverty. J Bus Manag Soc Sci Res (JBM\&SSR) 1(1):1-12 Google $\underline{\text { Scholar }}$

25. Stadelmann M, Michaelowa A, Roberts T (2011) New and additional to what? Assessing options for baselines to assess climate finance pledges. Clim Dev 3:175-192CrossRefGoogle Scholar 
26. Sterk W, Luhmann H-J, Mersmann F (2011) How much is 100 Billion US dollar. Friedrich-Ebert-Stiftung, BerlinGoogle Scholar

27. Transparency International (2018) Corruption perceptions index global analysis. Transparency International, BerlinGoogle Scholar

28. UNCTAD (2015, Dec) New and additional climate finance a continuing lack of clarity. United Nations conference on trade and developmentGoogle Scholar

29. UNEP (2018) The emissions gap report 2018. United Nations Environment Programme, NairobiGoogle Scholar

30. UNFCCC (2015) Paris agreementGoogle Scholar

31. UNFCCC (2018) 2018 Biennial assessment and overview of climate finance flows technical report. UNFCCC Standing Committee on Finance, BonnGoogle Scholar

32. WEF (2018) Two degrees of transformation businesses are coming together to lead on climate change. Will you join them? p 16. Retrieved 3 Feb 2019, from World Economic Forum.

http://www3.weforum.org/docs/WEF_Two_Degrees_of_Transformation.pdf

33. UNFCCC (2019) Introduction to Climate Finance https://unfccc.int/topics/climate-finance/the-big-picture/introduction-to-climatefinance

34. Weikman R, Roberts T (2019) The international climate. Climate and developmentGoogle Scholar

35. Westphal M, Canfin P, Ballesteros A, Morgan J (2015) Getting to \$100 billion: climate finance avenues and scenarios to 2020 . World resources Institute working paper, WashingtonGoogle Scholar

36. Zhang W, Pan X (2016) Study on the demand of climate finance for developing countries based on submitted INDC. Adv Clim Chang Res 7:99104CrossRefGoogle Scholar

\section{How to cite this article:}

Motty M., Ackom E.K. (2019) Climate Finance: Unlocking Funds Toward Achievement of Climate Targets Under the Paris Agreement. In: Leal Filho W., Azul A., Brandli L., Özuyar P., Wall T. (eds) Climate Action. Encyclopedia of the UN Sustainable Development Goals. Springer, Cham 
